logos_i_ethos_2013_2_(35), s.43-54

Marian Jaworski

\title{
Eidos chrześcijaństwa w nawiązaniu do poglądów Romano Guardiniego
}

\section{Wprowadzenie}

Filozofia żywego konkretu Romano Guardiniego

Ażeby zrozumieć dobrze myśl Romano Guardiniego na temat tego, czym jest chrześcijaństwo, trzeba się odwołać do jego filozofii żywego konkretu, a zwłaszcza do jego teorii o przeciwieństwie ${ }^{1}$.

Guardini, dążąc do przezwyciężenia racjonalizmu, w problematyce poznania Boga nawiązał do fenomenologii Maxa
Marian Jaworski - ur. 1926, arcybiskup lwowski, doktor teologii, profesor filozofii. W ponad 150 publikacjach, których jest autorem, zapoczątkował i rozwijał polską fenomenologię religii oraz wielokrotnie podkreślał niezbywalną rolę sacrum $\mathrm{w}$ tworzeniu przestrzeni sensu człowieka. Tytuł dra hab. uzyskał w 1966 r. na podstawie rozprawy Poznanie religijne Boga u Romana Guardiniego.

Schelera. Rozwinął przy tym te pierwiastki jego systemu, które łączą go z filozofią życia reprezentowaną przez takich myślicieli, jak Simmel, Dreisch. Filozofia żywego konkretu specyfikuje w ten sposób jego pogląd na stosunek poznania między religią a filozofią, konformizmu pomiędzy religią a filozofią.

Dotychczasowe próby - zdaniem Guardiniego - na temat poznania żywego konkretu bytu były jednostronne. Średniowiecze stało na stanowisku, że nie można naukowo ująć bytu konkretnego. Racjonalizm doprowadził to stanowisko do skrajności. Poznanie utożsamia się z poznaniem naukowym, a więc pojęciowym. Powyższe próby nie mogły czynić zadość prawdziwemu poznaniu żywego konkretu.

R. Guardini, Der Gegensatz. Versuche zu einer Philosophie des Lebendig-Konkreten, Mainz 1925. Por. również tenże, Bóg daleki - Bóg bliski, tłum. J. Koźbiał, Poznań 1991, s. 199-200. 
Poznanie pojęciowe skierowane jest na to, co ogólne, abstrakcyjne, na element formalny w przedmiocie konkretnym, pomija natomiast treść indywidualną.

Temu jednostronnemu podejściu do bytu konkretnego przeciwstawiono podejście irracjonalne. Najbardziej skrajne sformułowanie tego sposobu poznania odrywa go całkowicie od rozumu i mówi o poznawaniu przez „uczucie” czy ,instynkt”. W tego rodzaju zapatrywaniach jest - według Guardiniego - wiele racji. Istnieje bowiem taki proces poznawczy, który można określić jako ogląd. Trzeba jednak wyjaśnić, na czym polega istota tego oglądu, wskazać, czym różni się od zmysłowego oglądu, a także od pojęcia z jednej strony, a od uczucia z drugiej strony.

Według Guardiniego żywy konkret może być ujęty tylko wtedy, gdy równocześnie posłużymy się poznaniem pojęciowym i intuicją. Konkretny akt poznawczy urzeczywistniający się w tym napięciu „pojęcie - intuicja” skierowany jest na byt konkretny, żywy. W tego rodzaju akcie poznawczym intuicja i proces pojęciowania są wspólnie związane, ale nie w sposób syntetyczny, ale tak, jak to ma miejsce w stosunku przeciwieństwa: wspólnie tworzą jeden konkretny akt. W konkretnej strukturze tego aktu leży jego przystosowanie do konkretnego przedmiotu poznania. Jest to więc akt intuicji, ale przez jednoznaczną linię pojęciową skierowany na logicznie określony cel. Duża miara intuicji kształtowana przez dużą miarę siły pojęciowej. Tego rodzaju intuicja nabiera przez to nowego charakteru. Guardini nadaje jej miano oglądu.

Wynik tego procesu poznawczego jest konkretny: jest ponad pojęciem i intuicją. Posiadający naturę napięcia akt poznawczy można oddać bezpośrednio w konkretnej postaci, w pewnym czynie, symbolu, w akcie własnego bytu. Jeżeli wypowiedź ta ma posiadać charakter naukowy, trzeba się posłużyć znowu pojęciami. W ten sposób treść oglądu zostaje sprowadzona $\mathrm{z}$ powrotem do tego, co stanowi element poznawczo-pojęciowy. Jednak to ujęcie - zauważa Guardini - będzie o wiele pełniejsze i słuszniejsze, jeśli będzie spoczywać na zupełnym i bogatym oglądzie, aniżeli tylko na samych operacjach pojęciowych. 
Fenomenologia Schelera, do której nawiązuje Guardini, mówi nie tylko, że ujmuje sam konkret, ale równocześnie to, co jest trwałe i niezmienne - istoty rzeczy ${ }^{2}$.

\section{Stanowisko filozofii średniowiecznej i św. Tomasza z Akwinu}

Stanowisko Guardiniego różni się od przekonań filozofii średniowiecznej m.in. w kwestii poznania naukowego. Stanowisko św. Tomasza z Akwinu na swój sposób jednak winno być przez tomistów rozwinięte współcześnie. Wskazuje na to Georges Van Riet w swym artykule Y a-t-il chez Saint Thomas une philosophie de la religion??3.

Według św. Tomasza z Akwinu - tak jak dla Arystotelesa - nie ma wiedzy jak tylko o tym, co jest powszechne i konieczne; konkret, to, co przygodne, historyczne jako takie wymyka się wiedzy. Filozofia religii w ogóle dotyczy struktur odniesienia człowieka do Boga. Ona osiąga prawdę; ona realizuje w pełni pojęcie wiedzy. Filozofia religii chrześcijańskiej jest wiedzą w sensie niedoskonałym. Stara się zrozumieć tajemnice chrześcijańskie, które są dla nas przygodne, przynajmniej w tym sensie, że wiedza, którą z nich czerpiemy, jest „darmowa”, gdyż osiągana dzięki objawieniu historycznemu.

Zdaniem Van Rieta św. Tomasz miał świadomość granic swojej filozofii, lecz nie wskazał założeń metody, którą się posługiwał. Jego filozofia religii, jak zresztą cała filozofia, jest istotowo, strukturalnie metafizyczna. Uwagi metodologiczne są ubogie i niezupełne. Dlatego nie zadowalają współczesnych umysłów. Ażeby uczynić ją przystępną dla umysłowości współczesnej, należy rozwinać to, co dotyczy metody; uzupetnić syntezę porządku metafizycznego przez epistemologię $e^{4}$ (o tym powiemy jeszcze w dopowiedzeniu artykułu).

\footnotetext{
Więcej na temat filozofii żywego konkretu zob. w: M. Jaworski, Religijne poznanie Boga według Romano Guardiniego, [w:] tenże, Wybór pism filozoficznych, Olecko 2003, s. 19-55.

G. Van Riet, Philosophie et religion, Louvain-Paris 1970, s. 65-105.

Tamże, s. 104.
} 


\section{Eidos chrześcijaństwa w ujęciu Romano Guardiniego}

\section{Główne zadanie badań filozoficznych Romano Guardiniego}

Jak założenia teoriopoznawcze poznania żywego konkretu przeniosły się na pracę badawczą nad istotą chrześcijaństwa Guardiniego?

Po mianowaniu Guardiniego na profesora światopoglądu chrześcijańskiego w Berlinie Scheler, dodając mu odwagi do przyjęcia tego stanowiska, powiedział do niego: „[ksiądz] musi ukazywać to, co się zawiera w słowie «światopogląd»: rozważać świat, rzeczy, człowieka, dzieła, ale jako świadomy odpowiedzialności chrześcijanin i na płaszczyźnie naukowej mówić to, co ksiądz widzi, ogląda"5.

Guardini na swój sposób - to znaczy: dążąc do oglądu - zmierzał do coraz pełniejszego poznania tego, co stanowi eidos chrześcijaństwa, tego, co stanowi jego tożsamość, co oznacza całokształt jego istnienia. Mając to na względzie, dążył on stale do coraz bogatszego i pełniejszego ukazania, czym jest chrześcijaństwo samo w sobie, w swej odrębności w stosunku do innych religii i do tego, co jest świeckie. Podejmował podstawowe tematy: objawienie, wolność, łaska. Miarą tej prawdy był dla niego sam Jezus, tajemnica Jego samego. A On jest Panem. Dlatego jednym z głównych dzieł Guardiniego jest Der Herr. Betrachtungen über die Person und das Leben Jesu Christi (Pan. Rozważania o osobie i życiu Jezusa Chrystusa $)^{6}$.

Niestety, polskie tłumaczenie ${ }^{7}$ rozminęło się z ideą Guardiniego w samym tytule, który brzmi Bóg: Nasz Pan Jezus Chrystus - osoba $i \dot{z} y c i e$. Nie wiadomo, dlaczego tak zrobiono. Przedmowa Felixa Messerschmida na s. 5-9 tego nie wyjaśnia i nie jest najlepszym wprowadzeniem do tego, czym w rzeczywistości jest Der Herr. Nie tylko nie mówi o tym, czym jest to dzieło, ale nie pozwala dostrzec, o co

\footnotetext{
H. B. Gerl, Romano Guardini, Mainz 1985, s. 166.

6 R. Guardini, Der Herr. Betrachtungen über die Person und das Leben Jesu Christi, Wuerzburg 1937.

Tłum. J. Zychowicza z 1999 roku.
} 
chodziło Guardiniemu i stanowi wręcz pewną jego deprecjację. Czytamy w niej: „niniejsze «rozważania» nie roszczą sobie pretensji do wyczerpania tematu. Nie próbuja przedstawić spójnie życia Jezusa, lecz wybierają z niego poszczególne słowa i wydarzenia. Nie zamierzają ukazywać $z$ logiczna konsekwencja Jego postaci, lecz rysują to tę, to inną cechę - w miarę tego, jaki nabierają one żywego charakteru. Nie jest to rozprawa naukowa $\mathrm{z}$ dziedziny historii czy teologii, lecz konferencje duchowe, wygłaszane w ciągu czterech lat podczas niedzielnej liturgii, które nie miały na celu nic innego, jak tylko pełnienie według swej możności misji zleconej przez samego Pana, głoszenie Jego, Jego orędzia i Jego dzieł".

Nie można się zgodzić, że Der Herr nie „próbuje przedstawić spójnie życia Jezusa” i nie zamierza „ukazywać z logiczną konsekwencją Jego postaci". Guardini, idąc za radą Schelera, starał się ująć osobę Jezusa Chrystusa w jej jedyności i niepowtarzalności. On jest Panem, der Herr, Kyrios.

\section{Nauka Pisma Świętego: Jezus jest Panem}

Wiadomo, że tytuł „Pan” był przyznawany Jezusowi od samego początku, czego dowody przedstawia nam św. Paweł w cytowanych przez siebie wczesnochrześcijańskich wyznaniach wiary: „Panem jest Jezus” (Rz 10, 9). Określenie to wyraża więc tajemnicę Chrystusa, Syna Człowieczego i Syna Bożego; już ze Starego Testamentu bowiem wynika, że słowo „Pan” (Adonaj = Kyrios) jest nie tylko tytułem królewskim, lecz także imieniem Bożym.

Jako Król, Jezus jest Panem wszystkich ludzi (Rz 14, 9), wszystkich swoich nieprzyjaciół i potęg (Kol 2, 10-15), czy śmierci (1 Kor 14, 24-57, por. 1 P 3, 22), panów ziemskich, którzy reprezentują wobec swych niewolników jedynego Pana (Kol 3, 22 - 4, 1; Ef 6, 5-9); jest On wreszcie Panem Kościoła, swojego własnego Ciała, nad którym panuje i które wa 1999, s. 6 .

$8 \quad$ R. Guardini, Bóg: Nasz Pan Jezus Chrystus - osoba i życie, tłum. J. Zychowicz, Warsza- 
karmi (Kol 3, 18; Ef 1, 20n; 4, 15; 5, 22-32). Dlatego też cały wszechświat, niebiosa, ziemia i podziemia głoszą, że Jezus jest Panem (Flp 2, 10n).

Spróbujmy również w duchu Guardiniego nawiązać do Objawienia danego Abrahamowi, by lepiej to zrozumieć. Bóg, który objawił się Abrahamowi, ojcu naszej wiary, zawiera z nim przymierze i mówi do niego, że On jest jego Panem. Pierwszym więc określeniem Tego, który przychodzi do Abrahama, jest Pan, ten, który go wzywa do więzi z sobą! Do bycia z Nim, które będzie stopniowo coraz bardziej szczegółowo określane. I ten, który w ten sposób się objawia, jest prawdziwym Bogiem, najwyższym i jedynym. Gdy Abraham miał 99 lat, a więc już po wyjściu z ziemi rodzinnej, po pobycie w Egipcie, rozstaniu się ze swym bratankiem Lotem i wyprawie wojennej królów mezopotamskich, zapowiedzi Boga o licznym potomstwie Abrama, narodzeniu pierworodnego Izmaela, Pan rzekł do niego: „Jam jest Bóg wszechmogący, służ mi, bądź nieskalany”. W dalszej historii Abrama (Abrahama) termin „Pan” występuje tam, gdzie Bóg wkracza w dzieje, w życie Abrahama (Rdz 12, 1; 7, 17, 1; 13, 14-15; 15, 7; 18, 1n).

Jezus objawia się również jako Pan. Jest to także podstawowe Jego określenie i na tym polega Jego ogląd i nasza wiara. „Jeżeli więc ustami swoimi wyznasz, że Jezus jest Panem i w sercu swoim uwierzysz, że Bóg wskrzesił Go z martwych, osiągniesz zbawienie” (Rz 10, 8b-9).

\section{Na czym zasadza się treść „Jezus jest Panem” u Romano Guardiniego?}

Guardini ukazuje w wielu miejscach swej książki Der Herr, że Jezus $\mathrm{w}$ swoim własnym imieniu ujawnia, na czym polega Jego panowanie i przymierze. I co nowego wymaga od swoich wyznawców, którzy za Nim pójdą. Nie jest tylko Mojżeszem, który ustanawia Prawo w imieniu Jahwe, ale sam od siebie w wielu miejscach mówi: „A Ja wam powiadam..."

Nawiązując do Guardiniego, postaram się pokazać to w nauczaniu Jezusa o małżeństwie, dziewictwie i błogosławieństwach, nie sposób bowiem przeanalizować wszystkich wypowiedzi teologa na ten temat. 
Faryzeusze, chcąc wystawić Jezusa na próbę, zadali Mu pytanie: „Czy wolno oddalić swoją żonę z jakiegokolwiek powodu?” (Mt 19, 3) ${ }^{9}$. Jezus odpowiada, że Stwórca od początku stworzył ich jako mężczyznę i kobietę. I rzekł: „Dlatego opuści człowiek ojca i matkę i złączy się ze swoją żoną i będą oboje jednym ciałem. Co więc Bóg złączył, człowiek niech nie rozdziela" (Mt 19, 4-6).

Faryzeusze dobrze rozumieją Jezusa i to, że to, co mówi, różni się zasadniczo od tego, co powiedział Mojżesz, który w przypadku oddalenia żony kazał jej dać list rozwodowy. Zwracając uwagę, że Mojżesz uczynił tak ze względu na zatwardziałość Żydów, Jezus dodaje od siebie: „A Ja powiadam wam: kto oddala swoją żonę - chyba w przypadku nierządu - popełnia cudzołóstwo. I kto oddaloną bierze za żonę, popełnia cudzołóstwo". Uczniowie są wstrząśnięci: być może przypominają sobie słowa Jezusa z Kazania na górze: „Słyszeliście, że powiedziano: Nie cudzołóż. A Ja wam powiadam (podkreślenie moje - M. J.): każdy, kto pożądliwie patrzy na kobietę, już się w sercu swoim dopuścił z nią cudzolóstwa" (Mt 5, 27n).

Istnieje jeszcze jeden porządek, daleki od tego, co każdy „może pojąć”! Chodzi o rezygnację z wszelkiej więzi płciowości, która wynika z wolnej woli, ze względu na królestwo niebieskie. W nim człowiek całą swoją moc miłości ukierunkowuje wprost na Boga i Jego królestwo, i dopiero od Niego przychodzi do człowieka. Na ten temat powiedziane jest w Prawie jeszcze mniej. W jeszcze większej mierze stosuje się do tego zdanie: „Kto może pojąć, niech pojmuje (Mt 19, 12)”.

Pytano, który z tych dwóch porządków ma wyższą rangę. Do pytania tego - pisze Guardini - powrócimy później. Tutaj możemy powiedzieć tylko tyle, że według słów Pana oba one pochodzą z tego samego źródła. Oba zawierają w sobie w stosunku do samej natury pewną tajemnicę. Oba zmierzają do czegoś większego, niż to, co każdy „może pojąć”. Żadnego z nich nie można wywieść tylko z bezpośredniego sensu popędu czy ludzkiej społeczności, czy serca, lecz można je poznać dopiero w świetle Objawienia, przyjąć na zasadzie wiary i spełnić dzięki łasce. 
Guardini podkreśla, czym jest nauczanie Jezusa na temat małżeństwa i dziewictwa. „Te słowa Pana od dwóch tysięcy lat określały ludzka egzystencje w jej najbardziej żywych siłach i nadal są aktualne”. I dalej: „Tego, na czym polega chrześcijański ład seksualny, nie można określać na podstawie doktryny prezentowanej przez jednego czy drugiego chrześcijańskiego myśliciela, lecz jedynie na podstawie woli Jezusa. To On stoi ponad wszystkimi - również ponad największymi świętymi i doktorami Kościoła" ${ }^{\prime}$.

Pełne znaczenie tego, że Jezus jest Panem, odnajdujemy m.in. w Jego nauce o Błogosławieństwach. W Kazaniu na Górze (Łk, Mt) bardzo mocno ukazuje się całkiem nowa egzystencja człowieka, którą przynosi Jezus.

Błogosławieni jesteście wy, ubodzy, albowiem do was należy królestwo Boże.

Błogosławieni wy, którzy teraz głodujecie, albowiem będziecie nasyceni.

Błogosławieni wy, którzy teraz płaczecie, albowiem śmiać się będziecie.

Błogosławieni będziecie, gdy ludzie was znienawidzą i gdy was wyłączą spośród siebie, gdy zelżą was i z powodu Syna Człowieczego podadzą w pogardę wasze imię jako niecne (Łk 6, 20n).

„Mamy wszelki powód, aby zapytać, co te cztery zdania (Łk 6, 24n, Mt 5, 3-12) oznaczają. Kryje się w nich coś, co przekracza wszystkie bliskie nam kategorie myślenia, coś rewolucyjnego" ${ }^{11}$. Ale co to jest? Po przedstawieniu prób interpretacji, których Guardini nie podziela, pisze on: „Zbliżamy się do niej dopiero wychodząc od najgłębszej istoty chrześcijańskiego orędzia: «wszystko przekazał mi Ojciec mój. Nikt nie zna Syna, tylko Ojciec, ani Ojca nikt nie zna, tylko Syn i ten, komu Syn zechce objawić. Przyjdźcie do mnie wszyscy, którzy utrudzeni i obciążeni jesteście, a ja was pokrzepię. Weźcie moje jarzmo na siebie i uczcie się ode mnie, bo jestem cichy i pokorny sercem, a znajdziecie ukojenie dla dusz waszych» (Mt 11, 27n)”. I pyta Guardini: „Czy nie zawiera się

$10 \quad$ Tamże, s. 269.

11 Tamże, s. 71. 
w tym ta sama tajemnica, co w Błogosławieństwach?" Świadomość obalenia tego, co jest uznane i obowiązuje w świecie, aby wznieść to, co naprawdę istotne?

Jezus nie przychodzi po to, by do rzędu dotychczasowych zdobyczy ludzkiego umysłu dodać coś nowego; by wspiąć się na wyżyny przekraczające te, które już zostały osiągnięte; by ustanowić jakiś nowy ideał, jakiś nowy system wartości, na który przyszła właśnie pora. Nie! Jezus z zastrzeżonej dla Boga pełni niebios przynosi świętą rzeczywistość. Z Bożego serca wprowadza w spragniony świat strumień życia. „Od góry" otwiera nowe istnienie, którego nie może wydać z siebie sam świat stworzony i które jest zbudowane według zasad, jakie widziane „od dołu” sprawiają wrażenie zamętu i przewrotu (podkreślenie moje - M. J.). W tym wszystkim widać właśnie niepokojące, skłaniające do sprzeciwu „przewartościowanie wszystkich wartości ${ }^{12}$.

Jezus jest więc Panem w jedyny sposób! On przynosi święta rzeczywistość, na którą człowiek winien się otworzyć i stać się wolnym z woli Boga. Miarą zaś wolności jest miłość - a mianowicie miłość Boga.

Każdy czytelnik, który pod tym kątem widzenia - Jezus jest $\mathrm{Pa}$ nem - będzie czytał Der Herr Guardiniego, pozna lepiej, kim jest Jezus.

Zwróćmy jeszcze na koniec tych rozważań uwagę na artykuł Guardiniego opublikowany w 1937 roku, zatytułowany $\mathrm{Pan}^{13}$. Rozważanie to mówi o samym Jezusie - jako Panu - odsłaniając Jego inność w stosunku do wszystkich ludzkich i religijnych rozumień tego słowa. Nie jest On podobny ani do Buddy, otoczonego większą chwałą od chwały królewskiej, ani do Lao-tse, otaczanego boską czcią, ani do Mahometa, kroczącego przez świat na czele zwycięskich armii. „Całe dzieje Starego Testamentu ukierunkowane na przyjście Mesjasza przynoszą jako efekt końcowy zatwardziałość ludu i straszny los wysłannika Bożego. Cóż to za Bóg, którego Syn doświadcza takiego losu? Wyczuwamy tu inność chrześcijaństwa! Wszystkie inne «bóstwa» były siłami z tego świata, a świat uznaje i kocha tylko to, co jest z niego. A tu przychodzi coś spoza

12 Tamże, s. $70 \mathrm{nn}$.

13 Tamże, s. $153 \mathrm{nn}$. 
świata - więc też świat reaguje inaczej! Teraz zaczynamy rozumieć, co to znaczy: być chrześcijaninem. To znaczy pozostawać w bliskich stosunkach z tym Bogiem-tajemnicą - żyjąc w tym świecie takim, jakim jest. Musi to prowadzić do poczucia wyobcowania $\mathrm{z}$ tego świata, tym większego, im bliżej jest się Boga"14. W tym artykule R. Guardini do końca ukazuje, kim jest Jezus i co oznacza słowo „Pan”, co to znaczy być chrześcijaninem.

\section{Dopowiedzenie}

Na początku artykułu zwróciłem uwagę na metodę poznania żywego konkretu u Guardiniego i dla lepszego jej zrozumienia skonfrontowałem ją z metodą filozofii średniowiecznej, m.in. św. Tomasza. Analiza poglądów Guardiniego na temat Jezusa - jako Pana - pokazała nam przykładowo jej osiągnięcia. Prowadzi nas ona do poznania tego, co jest jedyne i niepowtarzalne i nawiązuje do współczesnej myśli filozoficznej, która bada nie tylko struktury powszechne i uniwersalne, ale nade wszystko stara się o poznanie tego, co jest indywidualne i przygodne - w oparciu o doświadczenie konkretu. Czy to stanowisko jest przeciwne filozofii św. Tomasza, czy też - przeciwnie - może prowadzić do jej kontynuacji, zgodnie ze współczesnym rozwojem myśli filozoficznej?

Van Riet, którego cytowałem we wstępie artykułu, mówi o zadaniach, jakie stoją przed tomizmem z naszych czasach. Według niego, jak zaznaczyłem, aby uczynić filozofię św. Tomasza przystępną dla mentalności współczesnej, trzeba uzupełnić syntezę metafizyczną przez epistemologię. Nie jest ona dyscypliną, która poprzedza metafizykę, lecz dyscypliną, która towarzyszy wszelkiemu wysiłkowi filozoficznemu i czyni go krytycznym. Nie ogranicza się tylko do preambula fidei, które poprzedzają wiarę efektywną, ale traktuje na równi wszelkie uwarunkowania racjonalne, od których zależy przeżywana wiara. I tak ograniczając się do Husserla i fenomenologów, można powiedzieć, że celem filozofii pozostaje poznanie istoty, ale metoda, którą się posługuje, jest nowa - poznanie

14 Brak źródła cytatu i strony 
fenomenologiczne nie jest ani realistyczne, ani abstrakcyjne, ale stara się poznać istotę w oparciu o przeżyty (doświadczony) konkret, w kontekście kultury i historii. W fenomenologii filozofia religii w ogóle i filozofia religii konkretnej nie różnią się tak, jak w perspektywie filozofii św. Tomasza. Pierwsza nie jest bardziej naukowa od drugiej. Co więcej: pierwsza następuje po drugiej. Rozpoczynamy od opisu konkretnych postaw religijnych i ich obiektywnych korelatów i dochodzimy do ujęcia istoty religii, a w konsekwencji do sądu dotyczącego wartości religii.

Gdy chodzi o chrześcijaństwo, pierwszym etapem będzie opis fenomenologiczny religii chrześcijańskiej. Nie będzie on bez analogii do filozofii religii św. Tomasza, pozostawiając na boku efektywny akt wiary (redukcja fenomenologiczna). Nie oznacza to jednak istot nierealnych czy czystych definicji nominalnych. Istoty, których ogląd osiągamy, są religijne, fenomenologicznie różne od istot świeckich.

$\mathrm{Na}$ podstawie tego, że znaczenia religijne są respektowane $\mathrm{w}$ ich specyfice, można dostrzec korzyść czysto filozoficznego studium chrześcijaństwa. Jednakże napotyka się tutaj również trudności. Opis fenomenologiczny stanowi pierwszy etap. Na nim nie wydajemy jeszcze żadnego sądu. Drugi etap polega na ukazaniu istoty religii i określeniu jej wartości. Van Riet nie rozważa wszystkich sposobów, w jakie filozofowie religii starają się rozwiązywać napotkane trudności. Wskazuje tylko przykładowo na próbę Henry’ego Duméry’ego i Paula Ricoeura.

Kończąc swój artykuł, Van Riet zauważa, że jego refleksja może się przynajmniej przyczynić do dostrzeżenia przeogromnego zadania, jakie jest do realizacji, jeśli chcemy pozostać wierni tomizmowi i uczynić owocnym wyjątkowe stanowisko św. Tomasza ${ }^{15}$.

Moje dopowiedzenie było konieczne przynajmniej z dwóch względów:

1) aby jeszcze lepiej zrozumieć metodę Guardiniego i jej znaczenie dla filozofii religii;

2) aby nie przeciwstawiać opacznie rozwoju współczesnej filozofii tomizmowi.

15 G. Van Riet, Philosophie et Religion..., dz. cyt., s. 101-106. 
Ad 1. Metoda filozofii religii przyjęta przez Guradiniego jest całkowicie zgodna ze współczesną filozofią. Starając się poznać żywy konkret, dąży do oglądu jego istoty, tego, czym on jest sam w sobie, w swej niepowtarzalności. W szczególny sposób pozwala nam na ogląd istoty chrześcijaństwa w jego odrębności od innych religii i od tego, co świeckie.

Ad 2. Jego metoda filozofii religii, zgodnie z postulatem Van Rieta uzupełnia naukę św. Tomasza o epistemologię, nawiązuje do metody fenomenologicznej, wychodzi naprzeciw rozwojowi współczesnej filozofii. Uzupełniony tradycyjny tomizm może w ten sposób stać się atrakcyjny dla współczesności.

Sądzę też, że bez tego nawiązania filozofia religii uprawiana w ramach tomizmu trzynastowiecznego będzie bliższa filozofii Boga aniżeli filozofii religii we współczesnym znaczeniu.

\section{Zakończenie}

$\mathrm{Na}$ naszym myśleniu religijnym ciąży jednostronne pojęcie Boga „ponad światem”. Jest ono słuszne, ale bezpośrednio nie mówi o Bogu, który przychodzi do nas. I stąd pokusa: żyjmy na ziemi tak, jakby Boga nie było! Sądzę, że w dobie współczesnego laicyzmu podstawowe pytanie metafizyczne, dlaczego jest raczej coś niż nic, trzeba uzupełnić równie podstawowym pytaniem: Kto jest Panem? Kim jest ten, który się objawia? Czy Jezus jest Panem? 